などがいわれている22,3)。そこでわれわれとしては，細 材として選鉱廃滓サイクロン,スピゴット,粗材としては さしあたり，山砂を用いるととして，種々と三軸圧縮試 験を行なつてみた。その結果は，従来いわれていること と.同様に，山砂，選鉱廃涬の比が $6: 4 \sim 7: 3$ の場合が 体積収縮率が少ない結果がでた。たまたま充墳必要量に 対し，採取可能な選鉿廃㳯の量が 3 割〜 4 割しかないこ とから，残りを山砂によることとし，現在では山砂，選 鈗廃㳯の比が $7: 3$ 程度で操業している。粗材としての 山砂は, 選鉱察滓に比し, 粒度の面で細かすぎるのでは ないかと考え，粗材として山砂にかえ 10 4 $4 \mathrm{~mm}$ の川砂 利を用いて，試験を行なつてみた。その結果 $83 \mathrm{~kg} / \mathrm{cm}^{2}$ の圧力に扝ける, 体積収縮量は, 山砂に比し, 収縮率に して 2 5\% 減じた。この減少はメリットとしては少な いが，流送の問題，原料の供給などの問題が解決すれば 使用してみてもよいと考えている。また山砂十選鉱廃漳 に10\%程度のセメントを混入することによつて，体積収 縮率を著じるしく減ずることができるのではないかとい う議論もあつて,これも試験を行なつてみた。その結果 は単なる山砂十選鉱廃㳯に比し体積収縮率で, 試験のた め丹念に 混合したもので 3 9\%，その試験材を実際に
坑内に流送したものでは，0 6\%の減少しか見られなか つた。コスト面を考慮するとこの程度のメリットでは問 題にならず，この案は放棄した。

\section{5. 結言}

勫迦内鉱山の概況，第 1 鉱体の採掘法選定の基礎とな る自然条件，採掘法，抒よび採掘法選定に際し行なつた 検討など，簡単に述べてきた。

現在は操業開始以来日が浅く, もちろん二次採掘に入 つた個所はないので，同採掘法についてよしあしを論ず る段階ではない。しかし現在，第 1 鉱体より同採掘法に より $10,000 \mathrm{t} /$ 月, また鉱体の形状の変化のため切羽の形 を少し考え，また切羽運搬をタイヤローダーよりスラッ シャ一に変えたが,基本的には同じ,一次を充塡式上向採 掘, 二次充塡式下向採掘によって行なら。第 3 鉱体よ り $5,000 t /$ 月, 計 $15,000 t /$ 月の出鉱を順調に行なつている。

\section{参 考 文 献}

1) 平松,岡：鉣柱にかかる地圧の光弾性実験による研究，日本鉣業 会誌79巻 905 号 昭和38年11月

2）西田，後藤：地表沈下防止のための 充填の効果に関する粒度別砂 利圧縮試験について, 九州鈗山学会誌 30 巻 8 号

3) パイエン社製：破硴空気充填機 VB-30型カタログ

\title{
松峰鉱床の採掘および採掘空間の処理方法 の計画について
}

\section{1. まえがき}

松峰鉱床は, 昭和 38 年 5 月, 坑外試錐によつてその端 緒をつかみ，その後約 140 本，49,000mに及ふ5 $50 \mathrm{~m}$ 間隔 のグリッドボーリングによつて, 鉱床のアウトラインを 把握することができた。

昭和41年 4 月現在の推定および予想釷量は，約 3,000 万 $\mathrm{t}$ である。

昭和 39 年 4 月から鉱床の開発を開始し，昭和41年10月 から 2 万 $\mathrm{t} /$ 月, 半年後に 3 万 $\mathrm{t} /$ 月, さらに 42 年10月か ら 4 万 $\mathrm{t} /$ 月の生産計画沿って開発中である。

\section{2. 地質鉱 床}

松峰鉱床は，花岡堂屋敷鉱床の南東約 $1.5 \mathrm{~km}$ にあり, 南北 $800 \mathrm{~m}$, 東西 $700 \mathrm{~m}$ の平面分布を示し, 深さは地表から $200 \sim 400 \mathrm{~m}$ の範囲にあり，地表は主として水田である。

* 同和鉱業株式会社 秋田釷業所花岡鉱山部

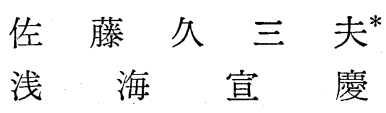

鉱床はいくつかの鉱床群に分けることができるが，一般 に上部から, 黒鉱, 黄鉱, 硫化鉄鉱, 石膏, 珪化帯, 流 紋岩の累帯構造を示寸層状黒鈗鉣床である。

地層は，地表から厚さ $20 \sim 40 \mathrm{~m}$ の砂砂層で始まり， これ接して泥岩と凝灰岩の互層（厚さ $200 \mathrm{~m}$ 前後）か. らなる不透水層が鉱床上盤として存在する（第 1 図，第 2 図参照)。 また，鉱床周辺は粘土帯が発達している。

\section{3. 開 発 の 概 要}

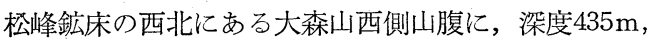
内径 $5.5 \mathrm{~m}$ の松峰立坑を設け, L $+72.5, \mathrm{~L} 195, \mathrm{~L} 260$, およびL 324 にプラットを設置し，鉱石，ズリ，材料運 搬，人員の昇降および入気に使用する。さらに，大森山 北側に坑口斜坑 $\left(4.0 \mathrm{~m} \times 2.95 \mathrm{~m}\right.$, 傾斜 $\left.28^{\circ}, 712 \mathrm{~m}\right)$ を設 け, L 180，L195，L260 で鉱床と連絡，排気，排水， 充填, 非常用人員通路および一部材運に使用する。 


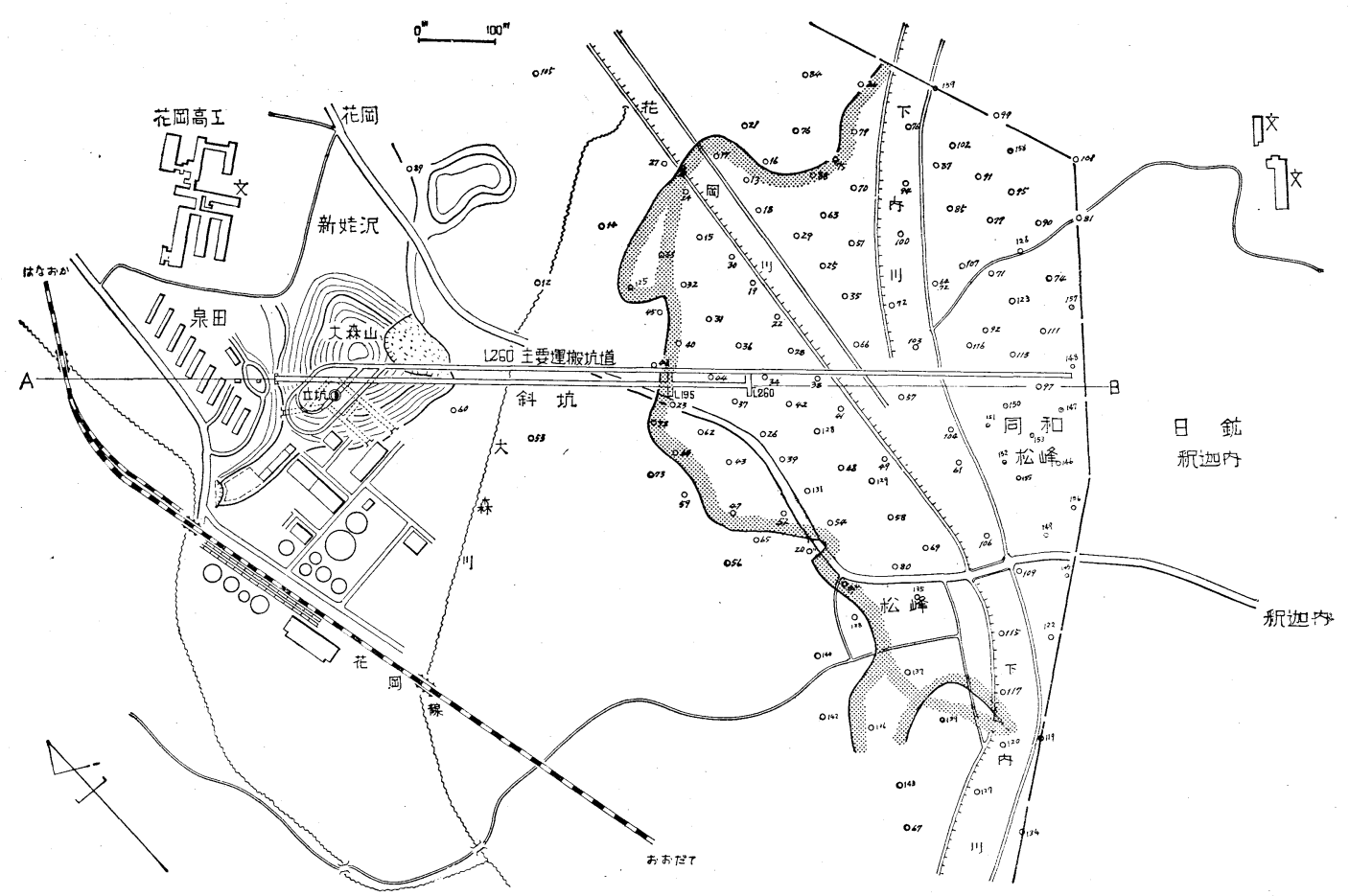

第1図松峰開 発計 画
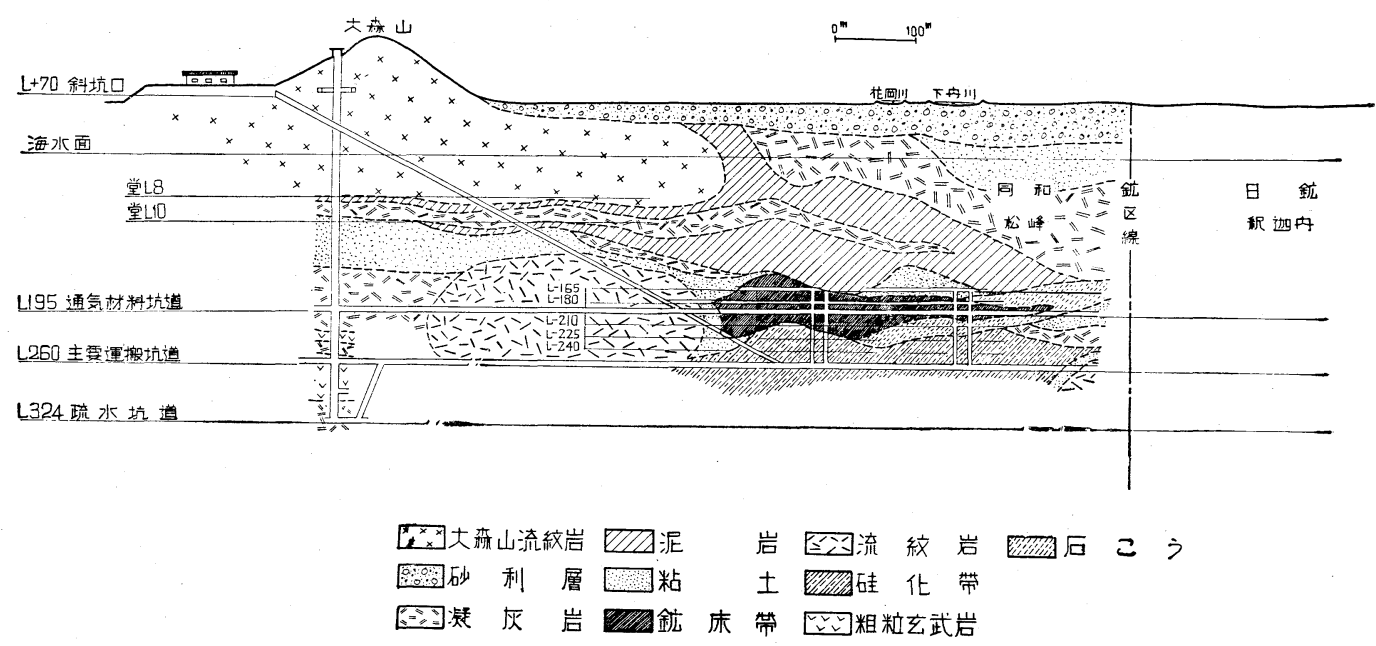

第2図松峰 断 面図 $\mathrm{A} \sim \mathrm{B}$

主要運搬坑道を L 260 に設け, 上部坑道から主要坑井 に投入した鈗石を，6t バッテリーロコ重連方式で $5 \mathrm{~m}^{3}$ 鉱車10両編成の列車に積込夕，松峰立坑に隣接して設け た破砕室まで運搬する。

L 195 以上を採掘するため，採掘基幹坑道を L 195 お よびL180 に，L260 主要運搬坑道に平行に重ねて開さ くする。L 195 は, 斜坑, 立坑に連絡し, 入気および中 段の鉣石，ズリ等の運搬レベルとして使用する。 L 180
は，松峰斜坑と連絡し，排気および切羽への材料配分レ ベルとして使用する。この他にL165，L150 を，ローカ ルの採掘レベルとして展開する。

各レベル間の採掘機械の移動，材料運搬，人員および 配管の通路，上部坑道展開の基地として， L 195 L 150 間に補助立坑または斜坑を開さくする。

最初L195 以上を採掘するが，L195，L180 の採掘基 幹坑道および上部坑道から採掘坑道を展開し，採掘鉱画蔀 
を設定し，切羽坑井を開さくして採掘を行なう。切羽坑 井に投入した鉱石を， $3 \mathrm{t}$ バッテリーロコおよび $1.2 \mathrm{~m}^{3}$ 鉱車の鉱石列車で引抜き，主要坑井に投入する。レール ゲージは $762 \mathrm{~mm}$ である。

なお松峰開発の特徵は，花岡本山の合理化を強力に推 進して捻出した人員によつて，直轄作業を行なつたこと である。

\section{4. 採掘法}

\section{$4 \cdot 1$ 鉱床の特徵}

昭和 40 年 9 月，L195 で鉱床内の坑道掘進を開始して 以来，41年 7 月までに，L 195，L 180 で $1,475 \mathrm{~m}$ の坑 道および坑井を開さく, 約 $4,400 \mathrm{~m}$ のアドバンスボーリ ングを実施し，鉣床の特徵をある程度把握することがで きた。

鉱床の特徴を列挙すると次のとおりである。

a . 粉状質および粘土質の黄鉱, 硫化鉄鉱が多い。

b. 夾み粘土が多い。

c . 鈗石が酸化しやすい。

d. 鉱床は不規則で, 鉣種の賦存状況もいり乱れて複 雑である。

松峰鉱床は, 花岡堂屋敷鉱床と同質の鉱床と考えて差 支えないようである。

\section{$4 \cdot 2$ 採掘の基本的な考え方}

a . 地表, 母岩の性状を考慮し, 切羽保安を主眼とし た, かつ地表への影響の少ない, 安 全確実な採掘法であること。

b．高品位鉱であるため，完全採 掘が可能なこと。

c . 機械, 設備の大型化, 切羽の 無支保化等による集約，高能率採掘 法であること。

d．松峰斜坑に平行に設けた採掘 :基幹坑道を中心として採掘坑道を開 さくし，上層から下層へ, 鉱床の周 辺から中心部に向つて順次採掘を進 める。

\section{$4 \cdot 3$ 採掘法の選定}

鉱宋の自然条件ならびに採掘法の 基本的考え方等を考慮して, 次の特 性を有する人工天盤による下向充圔 採掘法を採用することにした。

人工天盤による下向充塡採掘法の 特性

a. 人工天盤であるから切羽にお ける落石, 落盤災害がなく, 安全度 がきわめて高いこと。 b. 切羽の条件変化が少なく，安定した操業が行な え，採掘実收率が高いこと。

c 、総合能率がよい。

d．鉱石が軟弱でも採掘が確実で容易であること、

e. 充㙗コストがやや高くなること。

なお，採掘法検討の過程で, コンバインドメソッド ( 1 次上向充墺採掘，2次は上向または下向充塡採掘), ブッック採掘法等も検討したが，下記の点を考虑して見 送ることにした。

コンバインドメソッド

a . 松峰鉱床の条件が悪く，切羽の天盤掠よび鉱柱の 安全度が期待しにくいこと。

b. 理論的には充填率等ややすぐれているが，鉱床の 条件によっては，害質的に下向充填法と差はなくなるこ とも考えられること。

c．採掘実收率が低下寸るおそれがあること。

d. 2 次採掘では, 切羽保安の確保が特に困難である こと。

ブロック採掘法（鉱石を鉄筋コンクリートで囲み，採 掘する方法)

a .この方法でも沈下は避けられないこと。

b. 坑内でのコンクリート打ち工事は困難で，かつコ ンクリートブロックの強度も，期待ど掞りのものが得ら れにくいこと。

c .コストが著るしく高くなること。

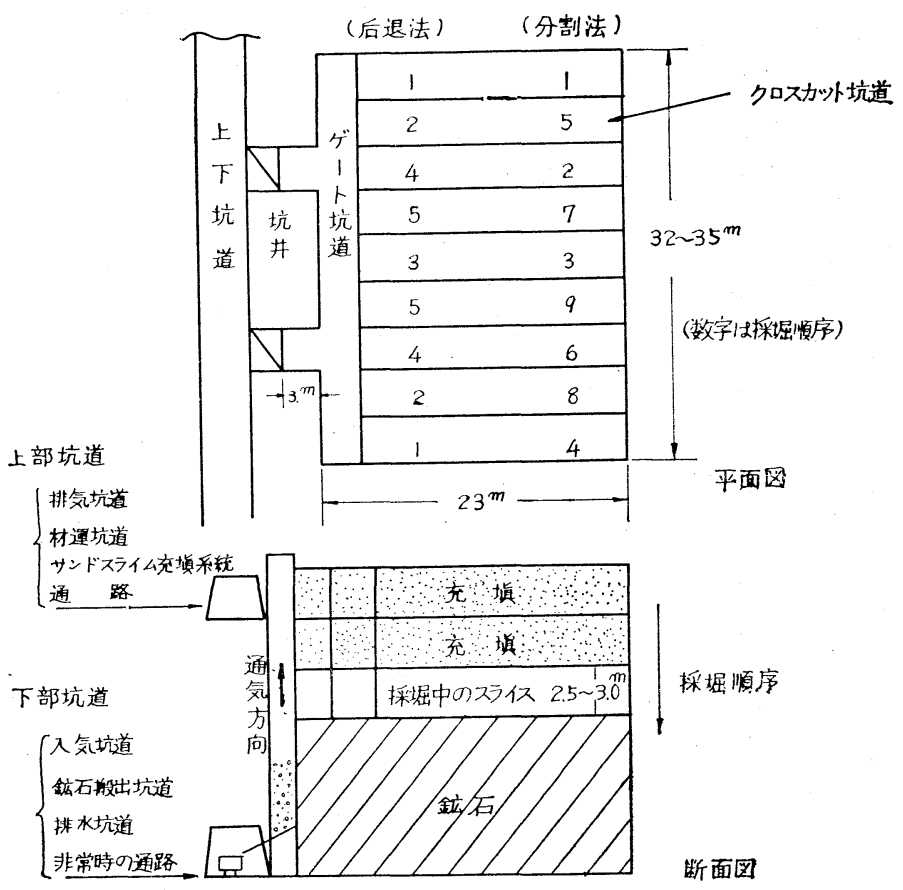

第3図採掘法模式図 


\section{$4 \cdot 4$ 採掘法の概要}

第 3 図の採掘法模式平断面図に示寸ように, 鉣画の標 準寸法は $(32 \sim 35 \mathrm{~m}) \times 23 \mathrm{~m}$ で，これを厚さ $2.5 \sim 3.0 \mathrm{~m}$ のスライスに分け，上層から順次下層へ採掘する。ク口 スカット坑道の長さは $20 \mathrm{~m}$ で, 鈗画に 9 10 本設ける。

各層の採掘は，各鉱画に 2 本の切羽坑井を設け，これ らからゲート坑道を掘進，これを基地としてクロタカッ 卜坑道を幅 $3.5 \sim 4.0 \mathrm{~m}$ で採掘し，鉱石はオートローダ 一で直接切羽坑井まで搬出する。クロスカット坑道の採 掘が終れば，床に鉄筋および金網をしき，脱水面を作製 して，15\%セメント配合のモルタル充塡を0.5 0.7m厚 さに実施し，さらにその上にサンドスライムを完全に充 填する。鉄筋入りのモルタル層は, 下層採掘時の人工天 盤となる。

各層の採掘は,クロスカット坑道を鉱画の両端から中 央に向つて後退式に採掘寸る方法と, クロスカット坑道 を 1 次と 2 次に分けて交互に採掘する分割法がある。分 割法では，2フェースを同時に稼働して各作業の手待ち をなくし平行作業を行なうことにより，1方 2 ラウンド を実施して能率を増大することが可能である。

搬出機械として，803 型ホッパーローダーを主とし， TL-3 型および TL-2 型オートローダーを使用する。ま た, 薄層部抢よび最上層では一部スクレーパーも使用す る。

切羽支保として三つ留を使用するが，三つ留の代りに 鉄柱等を使用することも考えられ，検討中である。

坑木使用量の少ない能率のよい採掘法として, 強固な 人工天盤沙潕支保採掘を研究している。現在，花岡 本山で試験操業を実施しているが，同切羽には鉄筋応力 計および土圧計を埋設して，地圧等の計測む平行して実 施中である。

採掘鉱画は, 切羽坑井によつて上下 2 本の坑道と連絡
する。おのおのの坑道の持つ役割は第 3 図のとおりであ る。

採掘鉱画は, 採掘坑道の両側または片側に設定し, こ れらの採掘完了と共に，採掘坑道を含む鉱柱も人工天盤 による下向充塔採掘法で, 鈗床の端から後退式に採掘す る。

\section{5. 採掘空洞の処理方法}

\section{$5 \cdot 1$ 充壃方式}

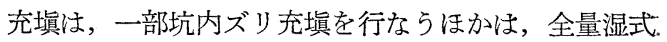
充塡方式とし，モルタル充塡も可能なものであつて，採 掘空洞は全部充填する。

充填設備は, 松峰選鉱場に隣接して設け, 充填斜坑, 松峰斜坑，L180 を経由して採掘切羽まで $2 \frac{1}{2}$ in 流送管 を敷設する。

\section{$5 \cdot 2$ 充 填 材}

充填材は，松峰選鉱場から産出するサンドスライムを 主体とするが，精鉱歩留が 55 60\% のため産出サンド 量が少なく，需要量を満たすことができない。不足分は 最初火山灰で充当するが，最終的には小坂製錬所のカラ ミを粉砕して使用する。

\section{$5 \cdot 3$ 採掘空洞の充填}

松峰鉱床の地表には，田圈，河川，集落が存在する が，鉱害を少なくするため，空洞の充填率を極力高める 必要がある。採掘空洞の充填率を向上寸るために次の対 策を推進する。

a. 採掘のスピードアップによる早期充填を実施す る。

b. 脱水面作製技術を向上して，充填率を高める。

c . 充填のパルプ濃度を高くして，充墴率を向上す る。

d. 充填完了の時期を明確に知る技術を確立する。
〈96〉ページり続く

片側にエアシリンダがあり鉱車の片側を最大 $60^{\circ}$ の傾斜 になるようもち上げます。 $60^{\circ}$ になると反対側のストッ パにぶつかりエアシリンダが収縮し鉱車が正常にもどる ようになつております。

東後 BLの無線操縦は立坑や坑井の投入, 積みこみに おける低速の場合ばかりでなく，全速で起つている場合 でもすべて制御を行なつているのですか，そうしますと 制御段数は何段ですか。

戥海 制御は全速の場合も低速の場合もすべて行なつて おり制御段数は 3 段です。
東後 3 段ですと大分段数がすくなく大まかな制御しか できないと思いますが，実操業上トラブルはありません か。

浅海 今までの所，特別卜ラブルはありません。 堀部 そろそろ時間がきたようですが何かございません か。では最後に花輪の方にお彗ね致します。トップスラ イシングを新たに始める場合，天盤がよくついてくるよ ら，天盤を少し積極的に破砕しておくと云われましたが 破砕する高さはどのくらいに考えられておりますか。 木村 $3 \mathrm{~m}$ ぐらいです。 堀部 それではこれで討論会を終了致します。 